\title{
REQUESTS FOR PROPOSALS IN STATE GOVERNMENT PROGUREMENT
}

The 1970's saw an unprecedented increase in procurement expenditures by state and local governments. ${ }^{1}$ Twenty years ago, federal procurement expenditures ${ }^{2}$ exceeded state and local purchasing by about $\$ 7$ billion each year. ${ }^{3}$ With the inception in the late 1960's of various grant-in-aid and revenue-sharing programs," state and local government purchases began to exceed those of the federal government. ${ }^{5}$ By 1980 , state and local procurement expenditures exceeded federal expenditures by more than $\$ 135$ billion. ${ }^{\circ}$

Despite this dramatic shift from the federal government to the states, most state procurement laws and regulations remain unchanged.7 These laws were generally enacted over fifty years ago, ${ }^{8}$ prior to the increases in volume, sophistication, and technological complexity of present state procurements. ${ }^{9}$

1 Bureat of Econ. ANalysis, U.S. Dep't of Compmerce, 1977 Bustness Stamstics 2 (21st biennial ed. 1978) [hereinafter cited as Business Statistics]; 61 Bureau of Econ. Analysis, U.S. Dep't of Commerce, No. 6, Survey of CurRENT BusInEss 12 (1981) [hereinafter cited as CuRrent BusINEss]. The following data culled from these reports indicate the dramatic economic shift from federal to state and local procurement:

Government Purchases of Goods and Services

(Billions of Current Dollars)

$\begin{array}{lcc}\text { Year } & \text { Federal } & \text { State and Local } \\ 1960 & 53.7 & 46.5 \\ 1970 & 95.6 & 123.2 \\ 1980 & 198.9 & 335.8 \\ 1981 \text { (estimate) } & 219.4 & 357.7\end{array}$

Although federal purchasing has increased fourfold since 1960, state and local purchasing has increased eightfold and now exceeds it by $\$ 135$ billion annually.

2 All references in this Comment to "federal procurement expenditures" include national defense purchases.

a Business Statisizcs, supra note 1 , at 2.

1 See Keyes, Some Approaches Toward a Uniform Code for State and Local Government Procurement-A Condition Ripe for a Solution, 6 Urb. LAw. 763, 765 n.1 (1974).

6 The Council of State Gov'ts, State and Local Governagnt Purcenasing 1.1 (1975) [hereinafter cited as State Purchasing].

6 See supra note 1.

7 See infra text accompanying note 66 and infra Appendix II. See also STATE Purcansing, supra note 5, at 1.2.

8 Short, Developments in State Purchasing, in 23 Boox of THE States 1980-81, at 213, 215 (The Council of State Governments ed. 1980).

9 Id. 217. 
The need for fundamental state procurement law reform was recognized in the early 1970's, ${ }^{10}$ and the American Bar Association responded by beginning to develop a model code.11 These efforts culminated in 1979, when the ABA House of Delegates ratified the Model Procurement Code for State and Local Governments (the Code). ${ }^{12}$ As of November 1981, eight states have enacted legislation based largely on that Code. ${ }^{13}$

The Model Procurement Code represents a significant improvement upon most current state laws, but it does not scrutinize all aspects of state procurement processes with the same thoroughness. ${ }^{14}$ Most importantly, the Model Procurement Code leaves the process of competitive negotiation ${ }^{15}$ largely undefined. ${ }^{16}$

${ }^{10}$ See, e.g., Falvey, Birnkrant \& Friedman, ABA Proposes Legislative Adoption of a Model Procurement Code for State and Local Governments, 11 UrB. LAw. 481 (1979); Hiestand, Blueprint for Improving Public Procurement, Cont. MGMr., Apr. 1979, at 6; Keyes, The Need for a Model Code on Purchasing by State and Local Governments, 43 PA. B.A.Q. 73 (1971); Keyes, supra note 4; vom Baur, The Project for a Model Procurement Code, 8 Pus. Cont. L.J. 4, 4-6 (1976); Assn. Recommends Study of Model Procurement Code for Pa., Pa. L.J.-Rep., Jan. 12, 1981, at 2, col. 2.

11 vom Baur, supra note 10, at 6-7.

12 Model Procurement Code for State and Local Governments vi (1879) [hereinafter cited as Model Procurement Code].

13 Arkansas, Colorado, Indiana, Kentucky, Louisiana, Maryland, South Carolina, and Utah have enacted Model Procurement Code-based legislation. The executive or the legislative branches in twenty-two other states are considering the adoption of all or part of the Code. See Model Procurement Code Project, Summary of Legislative Activity (September 1, 1981); infra Appendix II.

14 The Model Procurement Code has not gone uncriticized. For example, the National Association of State Purchasing Officials has criticized its proposed organizational alternatives and recommends adherence to existing structures wherever possible. See Short, supra note 8, at 215-16.

${ }^{15}$ See infra note 18 and accompanying text.

16 The Model Procurement Code provides for a kind of competitive negotiation process, termed "competitive sealed proposals." Moder Procurement Cone, supra note $12, \S 3-203$. But the circumstances under which a procurement officer may avoid the stated preference for formal advertising (competitive bidding), id. \$3-201, and resort to negotiations to let the contract are indefinite and elusive.

(1) Conditions for Use. When, under regulations promulgated by the Policy Office, the Chief Procurement Officer, the head of a Purchasing Agency, or a designee of either officer above the level of the Procurement Officer determines in writing that the use of competitive sealed bidding is either not practicable or not advantageous to the [State], a contract may be entered into by competitive sealed proposals. The Policy Office may provide by regulation that it is either not practicable or not advantageous to the [State] to procure specified types of supplies, services, or construction by competitive sealed bidding.

Id. $\$ 3-203(1)$. This provision essentially leaves the decision whether to employ "competitive sealed proposals" to procurement officers, who are to be guided by unspecified regulations and the expansive standards of "practicability" or "advantageousness." 
Competitive negotiation is very different from the standard public contracting method of competitive sealed bidding, which prohibits discussions between the government and all bidders, and permits consideration only of price in contract awards. ${ }^{17}$ In competitive negotiation, the government solicits design and price proposals from, and conducts negotiations with, suppliers ${ }^{18}$ in order to ascertain the best overall proposal in terms of both price and quality. ${ }^{13}$ Competitive negotiation is generally employed by the government to purchase sophisticated technology 20 that is produced by a limited number of suppliers and cannot be readily defined by precise specifications. ${ }^{21}$

The importance of negotiated procurement is evident from the marked trend toward its use. ${ }^{22}$ Despite federal statutory ${ }^{23}$ and regulatory ${ }^{24}$ provisions that require competitive bidding to be the primary contracting method, $85-90 \%$ of all federal contract dollars, amounting to over $\$ 175$ billion in 1980 , were let through negotiated procurements. ${ }^{25}$ Unfortunately, similar data on state government practices are not available. ${ }^{26}$ If, however, one speculates that negotiated procurement accounts for $10 \%$ of all state procurement spend-

17 Model Procurement Code, supra note $12, \$ 3-202(5)$ commentary (4).

18 Nash \& Love, Innovations in Federal Construction Contracting, 45 Geo. WAst. L. REv. 309, 324 (1977). For a broad definition of negotiation, see J. Whelan \& R. Paslex, Federax Government Contracts 178, 179-80 (1975). For an excellent, concise comparison of competitive bidding and negotiated procurement, see P. Shintrzer, Governarent Contract Bidding 20-22 (1976).

10 See Nash \& Love, supra note 18 , at 324,332 \& n.47. Negotiation is preferred when "[t]he comparability between initial offers . . . is insufficient to judge the relative merits on the basis of ... price [alone]." J. WheLAN \& R. Paslex, supra note 18, at 179; see also id. 181.

20 See vom Baur \& Del Duca, State and Local Procurement, in Developments in Government Contract Law 1977 at 287, 297 (M. Doke ed. 1978).

21 Comamission on Gov't Procurement, 1 Report of the Commission on Government Procurement 21 (1972) [hereinafter cited as Commisston Report.

22 See Commssion Report, supra note 21, at 20-21.

23 Both military and civilian federal procurement laws establish preferences for competitive bidding (formal advertising). Federal statutes authorize negotiated procurement only if formal advertising is "not feasible and practicable" and any one of a list of conditions is satisfied. 10 U.S.C. $\$ 2304$ (a) (1976 \& Supp. III 1979) (military); 41 U.S.C. $\$ \$ 5,252$ (c), 254 (1976 \& Supp. III 1979) (civilian). See Commisston REPORT, supra note 21, at 20.

24 Federal regulations also establish a preference for competitive bidding by requiring the use of formal advertising where "feasible and practicable under the existing conditions and circumstances." 32 C.F.R. \$2-102 (1979) (military); 41 C.F.R. \$1-1.301-2 (1980) (civilian).

25 Commission Report, supta note 21, at 20 \& n.25; R. Nase \& J. Cibinic, I Federal Procurement Law 317 (3d ed. 1977). See supta note 1.

${ }^{26} \mathrm{As}$ in the federal government, competitive bidding is the usual practice in all the states. See Short, supra note 8, at 214; infra Appendix II; see also STATE Purchastivg, supra note 5, at 6.6. 
ing (an extremely conservative estimate in light of the federal statistics), this amounts to $\$ 34$ billion in $1980 . .^{27}$

This Comment examines competitive negotiation in state government procurement. It focuses on the Request for Proposals (RFP), a document governments use to initiate the competitive negotiation process. After considering appropriate standards for the use of RFPs, this Comment discusses the need for protection from the cronyism and favoritism common in the letting of noncompetitive contracts by inefficient state purchasing systems. ${ }^{28}$ Finally, the Comment suggests statutory safeguards against capricious or dishonest administrative action ${ }^{29}$ and provisions that will enhance the effectiveness of judicial review of negotiated procurements. ${ }^{30}$

Part I of this Comment compares the salient features of competitive bidding and competitive negotiation, and considers ways in which both of these processes can be structured to maximize competition. Part II then discusses common problems in state negotiated procurement, using cases to illustrate particular diffculties. Part III introduces the Model Procurement Code, summarizes its provisions, and criticizes the Code. Finally, part IV presents and discusses the advantages of a proposed substitute for the Code's provisions on competitive negotiation.

27 See supra note 1 and accompanying text.

28 For examples of cases involving favoritism, collusion, and fraud in competitive bidding, see City of Oakland v. California Constr. Co., 15 Cal. 2d 573, 104 P.2d 30 (1940); Edward D. Lord, Inc. v. Municipal Utilities Auth., 133 N.J. Super. 503, 337 A.2d 621 (1975); Jered Contracting Corp. v. New York City Transit Auth., 22 N.Y.2d 187, 239 N.E.2d 197, 292 N.Y.S.2d 98 (1968). These problems have also been the subject of scholarly comment, e.g., IA C. ANTIEAU, MUNICIPAL Corporation Law $\$ 10.46$ (1980); 10 E. McQumlin, The Law of Municipal Corporations $\$ 26.69$ (3d rev. ed. 1981), and federal investigation, N.Y. Times, Sept. 13, 1981, $\$ 1$, at 39, col. 1 ("67 Counties Linked to Oklahoma Kickbacks").

29 For an example of existing statutory safeguards against dishonest official action, see 10 U.S.C. $\$ 2304$ (h) (Supp. III 1979). That statute states that no contract for transportation of government property may require cargo containers of any particular size, preventing procurement officers from steering contracts to carriers with odd sized containers. See also State Puncenasng, supra note 5, at 10.1-.6.

30 For examples of provisions contributing to effective judicial review, see 10 U.S.C. $\$ 2304$ (b) (Supp. III 1979); 41 C.F.R. $\$ 1-3.305$ (b) (1980). The regulations require officials who choose negotiated procurement over formal advertising to "set forth enough facts and circumstances to clearly and convincingly establish that the use of formal advertising would not have been feasible or practicable." 41 C.F.R. $\$ 1-3.305$ (b) (1980). This requirement, if strictly enforced, would provide a sufficiently detailed explanation for the choice of negotiation to permit courts to exercise effective judicial review.

The statute requires the agency to keep data respecting the negotiation of each purchase for six years, ensuring that courts will have an adequate record to review any legal challenge to a procurement. $C f$. State ex rel. E.D.S. Fed. Corp. v. Ginsberg, 259 S.E.2d 618, 626 (W. Va. 1979) (it would be "enormously useful" if agency filed written statement explaining contract award decision). 


\section{A Comparative Analysis of Government Contracting Methods: \\ The Need to Instrututionalize Competition}

Federal and state governments use both competitive bidding and competitive negotiation to procure goods and services. ${ }^{31}$ The two methods are predicated on different assumptions and address different governmental needs. Each method is discussed generally so as to highlight the importance of the differences between these two procurement methods. ${ }^{32}$

The description of competitive bidding is applicable to most state procurement systems. ${ }^{33}$ Because competitive negotiation originated in federal procurement practice $^{34}$ and has been adopted by states only recently, ${ }^{35}$ the description of that process is drawn from federal statutes and regulations.

31 P. Shatrzer, supra note 18, at 20; J. Wheran \& R. PASLEY, supta note 18 , at 175. In addition to competitive bidding and negotiation, some commentators identify "two-step formal advertising" as an alternative procurement method. See 40 Comp. Gen. 40 (1960); P. Sharrtzer, stupra note 18, at 193-200; Nash \& Love, supra note 18, at 322, 333-36; Short, supra note 8, at 214. See generally McClelland, Negotiated Procurement and the Rule of Law: The Fiasco of Public Law 87-653, 32 FondhaM L. Rev. 411, 422-25 (1964).

Two-step formal advertising, a hybrid of competitive bidding and negotiation, is largely a federal procurement method, and differs from competitive bidding only in permitting the procurement officer some initial flexibility before selecting the final bid solely on the basis of price. See 32 C.F.R. $\$ \$ 2-501$ to -503.2 (1979); 41 C.F.R. $\$ 1-2.501$ to $-2.503-2$ (1980). This method is, therefore, beyond the scope of this Comment, which focuses on competitive negotiation in state procurement.

This Comment refers to purchases involving only one offeror as noncompetitive negotiated procurement. Such procurements are generally permitted when there is only one possible supplier (sole source procurement), or for small purchases and emergency procurement. See 32 C.F.R. $\$ 3-210.2$ (i) (1979) (military sole source procurement); 41 C.F.R. $\$ 1-3.210(\mathrm{a})(1)$ (1980) (civilian sole source procurement); 32 C.F.R. $\$ 3-203$ (Supp. 1980) (military small purchases); 41 C.F.R. $\$ 1-3.203$ (1980) (civilian small purchases); 32 C.F.R. $\$ \$ 3-201$ to -202 (1979 \& Supp. 1980) (military emergency procurements); 41 C.F.R. $\$ \$ 1-3.201$ to -3.202 (1980) (civilian emergency procurement). Most state laws authorize noncompetitive procurements for small purchases, see STate Porcensing, stupra note 5, at A.I-.13 (Appendix A), and some allow them for emergency purchases, vom Baur \& Del Duca, supra note 20, at 321-22. Because of their relative infrequency, noncompetitive negotiated procurements are also beyond the scope of this Comment.

32 For comparisons of formal advertising and negotiated procurement, see $W$. Keyes, Government Contracts in a Nutshetr 175 (1979); P. Shinitzer, supta note 18 , at $20-22$.

33 See infra Appendix II.

34 For a discussion of the complexity of federal procurement practices, see CoMmasston REPORT, supra note 21, at 31-38.

35 See supra note 13. In 1978, Kentucky became the first state to enact legislation authorizing the use of RFPs in competive negotiation. Ky. REv. STAT. $\$ \$ 45 A .085-.090(2)$ (1980). See Pallo, Implementing the Model Procurement Code: Kentucky-The First Test, 8 Pun. CoNT. L.J. 14 (1976). 


\section{A. A Comparison of Competitive Bidding and \\ Competitive Negotiation}

Competitive bidding is the standard government contracting method. $^{36}$ Thirty-five states require formal advertising in a widely circulated newspaper, initiating competitive bidding, for all purchases exceeding a specified dollar amount. ${ }^{37}$ This enhances competition for a particular purchase ${ }^{38}$ and apprises the public of government purchasing activities. ${ }^{39}$

The document used to solicit bids is called an Invitation for Bids (IFB).40 The IFB contains the terms, conditions, and specifications of the purchase, ${ }^{41}$ describing in detail what the government seeks to procure. Whether the government needs goods or services, "[t]he unique feature of the . . formal advertising technique is its insistence on offers of products or services which are essentially identical, regardless of which competitor is selected." 42 Detailed specifications help ensure that competitors are placed on an equal footing, ${ }^{43}$ and, with all other factors standardized by the specifications, price becomes the determinative factor in the contract award.44

Bidders make their bids based upon the specifications listed in the IFB, without any discussions with government procurement officers. The bidder submits a sealed bid that cannot be changed or withdrawn. The bids are opened publicly at a time and place

${ }^{36}$ Every state has a statutory preference for government contracting by competitive bidding. See supra note 26. Federal statutes and regulations also reflect this preference. See supra notes 23-24 and accompanying text.

87 State Punchasing, supta note 5, at 6.4 .

${ }^{38} \mathrm{But}$ see id. ("In lieu of these requirements, a listing or an abbreviated type of public notice... is more reasonable").

39 Id.

40 The RFP is simply the initial solicitation of proposals from potential suppliers, and its issuance contemplates a procurement process involving negotiation with offerors. By contrast, the IFB is used to solicit firm and binding bids. Thus, this is not simply a difference in nomenclature. See J. Whelan \& R. Paster, stpra note 18, at 6; infra text accompanying notes 49-60. The decision to use an RFP represents a procurement officer's determination that the contract will be let by competitive negotiation instead of by competitive bidding. The failure to maintain this distinction between the initiating documents results in unnecessary confusion, and in litigation. See infra text following note 106.

41 State Punchasivg, supra note 5, at 6.5. For a detailed description of what an IFB should contain, see 32 C.F.R. $\$ \oint 2-200$ to -201 (Supp. 1980).

12 Comamssion REPORT, supra note 21 , at 19 (emphasis in original).

43 See Sweezey v. Mayor of Malden, 273 Mass. 536, 542, 174 N.E. 269, 271 (1931); State Purchasing, supta note 5, at 11.2.

44 See Commission Report, supra note 21 , at 18. 
designated in the IFB. ${ }^{45}$ Provided the bidder is responsible ${ }^{46}$ and responsive, ${ }^{47}$ the contract is awarded to the bidder submitting the lowest price. ${ }^{48}$

Competitive negotiation is an entirely different contracting process. The government solicits proposals, ${ }^{40}$ not bids, with a Request for Proposals. An RFP often contains only tentative assessments of what the government seeks to procure, rather than the definite and detailed specifications found in an IFB. ${ }^{50}$ In many instances, RFPs are used to initiate procurement of items for which adequate specifications are unavailable, ${ }^{51}$ such as research and development ${ }^{52}$ or sophisticated technology. ${ }^{53}$ Consequently, a procurement officer gains considerable flexibility by choosing competitive negotiation with an open-ended RFP, rather than competitive bidding with a carefully specified IFB.

45 Nash \& Love, supra note 18, at 312. See supra note 32.

46 "Responsibility" is defined as "the ability of a bidder or proposer for a government contract to satisfy the standards of a public procuring body, conditions which include: (1) adequate financial resources; (2) ability to comply with technical performance and delivery schedules; (3) satisfactory record of performance; (4) satisfactory record of integrity." W. KEYES, supra note 32 , at 92. See Gray, Responsiveness Versus Responsibility: Policy and Practice in Government Contracts, 7 Pub. Cont. L.J. 46 (1974); Nash, Survey of State and Local Government Contracts Law, 47 GEo. WAsr. L. Rev. 1085, 1102-33 (1979).

47 "Responsiveness" is defined as compliance with all material terms of an IFB. The federal regulations state that responsiveness to the timeliness of submission is necessary if "all bidders [are to] stand on an equal footing and the integrity of the formal advertising system [is to] be maintained." 32 C.F.R. \$2-301(a) (1979); 41 C.F.R. \$1-2.301(a) (1980); see also Nash \& Love, supra note 18, at 312 n.8. See generally Nash, supra note 46, at 1087-1101.

The federal regulations for negotiated procurement contain no concept comparable to responsiveness. 32 C.F.R. $\$ \$ 3-100$ to -1300.7 (1979 \& Supp. 1980); 41 C.F.R. $\$ \$ 1-3.000$ to .1220-14 (1980). Because specifications in many RFPs are skeletal or vague, the concept of responsiveness is generally inapplicable to negotiated procurement.

48 Nase \& Crbinc, supra note 25, at 224; Nash \& Love, supra note 18, at 312. For an exhaustive analysis of federal procedures for competitive bid opening and mistakes, see P. SHNTTZER, supra note 18, at 381-401, 449-483. For an overview of competitive bidding by state governments, see STATE PuRchasing, supra note 5 , at 2.1-.16.

49 Nash \& Love, supra note 18 , at 325 n.34.

50 See W. KEYEs, supra note 32 , at 175.

51 Federal regulations authorize the use of RFPs when specifications are inadequate. See 32 C.F.R. $\$ \$ 3-210.1,-210.2$ (xiii) (1979); 41 C.F.R. $\$ 1-3.210$ (a) (13) (1980). After negotiation, as the government nears the conclusion of the procurement process, the RFPs naturally become more specific. See C. DaNHOF; Governament Contracting and Technological Change 260 (1968).

52 See C. Dannof, supra note 51 , at 177,238 . Federal regulations authorize negotiated procurement of research and development. 32 C.F.R. $\$ 3-211$ (1979); 41 C.F.R. $\$ 1-3.211$ (1980).

53 For example, this Comment examines cases involving computerized lottery systems, data processing equipment, and a telecommunications system. See infra text following note 105. 
Procurement officials use RFPs when they are uncertain about what is available in the market or what can be produced. Discussions ${ }^{\mathbf{5} 4}$ with proposers are thus essential to ascertain more specifically what the government needs and whether it can be obtained in the market. After proposers reply to RFPs, for example, negotiations with each may begin, possibly leading to modifications of the RFP and amendments to proposals. Competitive negotiation, therefore, provides the officer with considerable latitude to clarify ambiguities, fill omissions, and correct defects in the original specifications. ${ }^{55}$

Competitively negotiated contracts are awarded on the basis of price and other evaluative criteria, ${ }^{56}$ provided the latter are stated in the RFP. ${ }^{57}$ Evaluative criteria may include quality standards, ${ }^{58}$ performance standards, ${ }^{50}$ or "life-cycle costing." ${ }^{60}$ Thus, the contract is awarded to the offeror who submits the best overall proposal in terms of both quality and price. ${ }^{61}$

In sum, competitive bidding is a rigid, uniform contracting method initiated by a specific solicitation in the form of an IFB. ${ }^{62}$ In contrast, competitive negotiation is a flexible approach initiated by a general, perhaps unspecified, solicitation in the form of an RFP. Decisions in the former case are based on price alone; in the latter case, price is only one factor in choosing the best overall proposal.

54 "Negotiation" and "discussion" are often used synonymously. See, e.g., 51 Comp. Gen. 102, 111 (1971).

55 This flexibility is limited by prohibiting government disclosure of information in a proposal to a competing offeror if that information would give the competitor an advantage in the negotiations. See, e.g., 32 C.F.R. $\$ \S 3-805.3(\mathrm{~b})$ to -805.3 (c) (1979); 41 C.F.R. $\$ 1-3.805-1$ (b) (1980).

56 Commssion Report, supra note 21, at 19 ("The single element which most acutely distinguishes negotiation techniques from formal advertising is the subjective judgment which weighs quality and other factors against price").

57 State Purchasing, supra note 5, at 6.7. In federal procurement, the RFP must list the evaluation factors to be used. 32 C.F.R. $\$ 3-501$ (M) (Supp. 1980); 41 C.F.R. $\$ 1-3.802$ (c) (1980).

58 Federal regulations authorize consideration of quality in civilian procurement. See 41 C.F.R. $\$ 3-101(6)$ (iii) (1980). The Model Procurement Code mentions price and quality "tradeoffs" in \$3-203 commentary (3)(a).

59 Nash \& Love, supra note 18 , at 325 n.35.

60 "Life cycle costing" is an accounting analysis used to determine the total cost of owning, operating, and maintaining a procured item with a measurable service life. Nash \& Love, supra note 18 , at 409 n.267 \& 410 . These costs are considered in addition to the acquisition price. State PuRchasing, supra note 5, at 11.8; Nash \& Love, supra note 18, at 409-10, 428. See infra text accompanying notes 156-57.

61 Nash \& Love, supra note 18, at 324. See generally State ex rel. E.D.S. Fed. Corp. v. Ginsberg, 259 S.E.2d 618, 624 (W. Va. 1979).

62 Some government defense contract analysts argue that, because of the restrictive nature of competitive bidding, a disproportionate amount of contracts is 


\section{B. The Need for Maximum Effective Competition}

It is a postulate of economics that competition minimizes the cost of goods to consumers. ${ }^{83}$ Competition also tends to improve the quality of goods purchased, to encourage innovation among suppliers, and to increase the buyer's choice. ${ }^{84}$ Competitive bidding assures competition by definition because it typically results in the lowest price to the purchaser. By tying negotiation to a competitive framework, the chance of obtaining quality, sophisticated goods at the lowest possible cost are clearly enhanced. Besides increasing economic efficiency in procurement, competition reduces favoritism and inspires confidence in the public procurement system. ${ }^{65}$ As a result, "it is essential that all acquisitions be made under conditions which foster competition among a sufficient number of potential vendors." 68

Competition, however, exists in different degrees in the marketplace, and varies widely among different products and services. ${ }^{67}$ For some goods and services, the market consists of similar or identical items that consumers choose on the basis of lowest price. For other items, there is either no clearly defined market, or quality differences are great but tend to be equalized by price variations. ${ }^{.8}$ Competitive bidding is the appropriate method where items are similar, ${ }^{69}$ because the desired items can be specified in detail. Competitive negotiation should be used when quality differences exist, ${ }^{70}$ because it gives procurement officers the opportunity to clarify available specifications and to consider quality in comparing prices.

Just as lack of competition may result in inefficient government procurement, too much competition may also create inefficiency in the negotiated procurement process. This observation raises the concern that states adopting competitive negotiation may also adopt the federal statutory requirement that "the maximum number of

let by the more flexible method of competitive negotiation. Morris, Some Facts of Life About Competition in Defense Procurement, 4 DEF. MGMт. J. 9 (1968), reprinted in $\mathrm{J}$. WhELAN \& R. PASLEY, supra note 18, at 316-18; see D. PACE, Negotiation and Managemant of Defense Contracts 84 (1970).

63 P. Samuleison, Economics 544 (10th ed. 1976).

64 See State Purchasing, supra note 5, at 6.2.

${ }^{65}$ Id.; accord W. KEYES, supra note 32, at 109.

${ }^{6}$ State Purchasing, supra note 5, at 6.2 (emphasis omitted). Cf. ComMISSION REPORT, supta note 21 , at 22 (recommending the use of competitive procurement procedures).

07 See Commission Report, supta note 21, at 19.

68 See Nash \& Love, supra note 18, at 338.

$89 \mathrm{Id}$.

70 $7 d$. 
qualified sources" be solicited in a negotiated procurement. ${ }^{71}$ But “[p]articipation by a 'maximum' number of firms . . . may unduly complicate the selection process and add considerably to both the procuring agency's and the offerors' costs." 72 In certain types of procurement, notably for research and development, the total cost of preparing and responding to RFPs may exceed the value of the contract. $^{73}$ Furthermore, soliciting the maximum number of potential offerors may result in diminishing the quality of the procured item. ${ }^{74}$ The goal of getting the best quality goods for the lowest price may therefore be subverted by a legal mandate to maximize competition.

Nash and Love suggest "maximum effective competition" 75 as a solution to this conflict between achieving economy and maximizing competition. They define maximum effective competition as tailoring both an agency's needs and the procurement process "to take advantage of the existing competition and to procure most economically a product that effectively satisfies its needs." 76 That is, an agency should maximize competition only to the extent that it is effective to procure what it needs. This, however, is a vague concept that must be clarified. ${ }^{77}$

One important step toward achieving maximum effective competition is to perform a market analysis. ${ }^{78}$ Such an analysis seeks to determine whether the particular item the agency needs can be procured on the open market, or whether it will require a contract for design or development. ${ }^{9}$ A thorough analysis should examine and reveal several characteristics of a market for a particular good

7110 U.S.C. $\$ 2304(\mathrm{~g})(1976)$.

72 Commassion Report, supra note 21 , at 23 . As a result of this argument, the Commission recommended "[a]djust[ing] the statutory provision on solicitations and discussions in competitive procurements other than formal advertising in the following manner: ... (b) Provide for soliciting a competitive rather than a 'maximum' number of sources, for the public announcement of procurements, and for honoring the reasonable requests of other sources to compete." Id. 22.

73 See Nash \& Love, supra note 18, at 338 n.61. Cf. Comanission Report, supra note 21 , at 23 ("Under [certain] circumstances, total solicitation costs may exceed the value of the contract").

74 See Nash \& Love, supra note 18, at 338 n.61.

75 Id. No state procurement law codifies this standard. See infra Appendix II. The Chiles bill, introduced in the 94th Congress, would have made maximum effective competition an explicit federal procurement policy. See S. 3005, 84th Cong., 2d Sess. $\$ 2(\mathrm{~b})(5)$, reprinted in 122 CoNG. Rec. 3762 (1976).

${ }^{76}$ Nash \& Love, supra note 18 , at 338 n.61.

77 This Comment expands the concept of maximum effective competition beyond the particular problem Nash and Love were discussing. See infra text following note 130.

78 Nash and Love, supra note 18, at 337-38.

79 See id. 337. 
or service. These include the number of potential offerors; whether the item to be procured varies in quality; whether the item's price varies greatly; how difficult it will be to specify what the agency wants; the expense involved in preparing an RFP and implementing competitive negotiation, and how costly it will be to respond to an RFP. ${ }^{80}$

Because relatively few states even authorize the use of competitive negotiation, ${ }^{81}$ state agencies do not perform market analyses. ${ }^{82}$ Thus, the chances of obtaining maximum effective competition are slim. Yet, procurement agency attempts to attain maximum effective competition, such as undertaking a market analysis, would link government procurement to particular market conditions. ${ }^{83}$ This linkage represents a substantial improvement over present statutes that either ignore economic realities by permitting only competitive bidding, ${ }^{84}$ or contain standards, like "feasible-practicable," that can be easily abused. ${ }^{85}$

The major obstacle to implementing state procurement systems based upon maximum effective competition is that states which accept the argument that competitive negotiation is desirable may adopt the federal standard for determining when competitive negotiation is to be used. Federal law requires competitive bidding "in all cases in which the use of such [a] method is feasible and practicable under the existing conditions and circumstances." 86 Otherwise, competitive negotiation may be used. ${ }^{87}$ Obviously, the federal

$80 \mathrm{~A}$ market analysis will not prevent corruption or favoritism, and will not ensure that officials will efficiently and honestly implement the appropriate procurement method. Requiring a written market analysis, however, will provide a reviewing court with the means to determine whether the procurement process up to that point has been characterized by arbitrariness. Given the present inadequacy of most state procurement laws, see supra notes $7 \& 35$ and accompanying text; infra Appendix II, a decision to employ competitive negotiation probably results in a waste of money, see supra text accompanying notes 71-74, and an increased possibility of litigation over the procurement. Thus, the importance of the procurement method chosen indicates that encouraging a careful choice of methods by requiring a market analysis is highly desirable.

81 See supra text accompanying note 35 and infra Appendix II.

82 There is no need to conduct a market analysis if the government can procure only through competitive bidding. Yet even the states that now authorize competitive negotiation do not require their agencies to conduct market analyses. See infra Appendix II.

88 The product or service that the agency seeks to procure defines the market, the market defines the procurement method, and the method determines whether the specifications will be broad (RFP) or narrow (IFB). A market analysis provides the crucial link between the first and second parts of this sequence.

84 See infra text accompanying note 94.

85 See infra note 88 and text accompanying notes 88 \& 89.

8610 U.S.C. $\$ 2304$ (a) (1976); 41 U.S.C. $\$ 252$ (c)(10) (1976).

8710 U.S.C. $\$ 2304$ (a) (1976); 41 U.S.C. $\$ 252$ (c)(10) (1976). 
"feasible-practicable" standard is quite vague,88 and it has gutted the statutory preference for competitive bidding. ${ }^{80}$ The standard offers procurement officials much discretion, and the public and competing offerors have little protection from either intentional or unintentional abuse of that discretion. ${ }^{00}$ Although it has been argued here that the states should use competitive negotiation more frequently, ${ }^{91}$ a shift from competitive bidding to competitive negotiation will be productive only if, ${ }^{92}$ unlike federal procurement, ${ }^{93}$ the conditions for using each method are clearly established by statute.

In sum, state procurement is currently characterized by distorting the meaning of competitive bidding to cover items for which competitive negotiation would work more efficiently. ${ }^{94}$ And in those states in which competitive negotiation is now statutorily authorized, the safeguards and provisions that would go far toward obtaining maximum effective competition are not in force. ${ }^{95}$

\section{Inadequate Statutes and the Mrsuse of Requests for Proposals Create Judicial Confusion}

Because most state laws authorize only competitive bidding, ${ }^{96}$ some state agencies try to adapt competitive bidding procedures to complex procurements. ${ }^{97}$ Yet, in many such cases, maximizing the

88 Neither the amendment promulgating this standard nor its legislative history reveals the meaning of "existing conditions and circumstances." Thus, it is easy to argue in any given procurement that competitive bidding would not be "feasible and practicable." Also, neither the amendment nor its legislative history specifies who makes the determination of feasibility and practicability. McClelland, supra note 31 , at 417 .

80 See supra notes $23-25$ and accompanying text.

90 See McClelland, supra note 31 , at $416-21$.

91 See supra text accompanying note 70 and following notes $27 \& 64$.

92 There are two problems with shifting too far toward competitive negotiation. First, all states adopting some form of competitive negotiation have based their legislation on the Model Procurement Code, see supra note 12 and accompanying text, which does not result in a particularly efficient form of competitive negotiation. See infra notes 174-89 and accompanying text. Second, overuse of competitive negotiation tends to nullify the statutory preferences for competitive bidding, see supra note 26 , which, when properly used, is the most efficient form of procurement. See supra text accompanying notes 63-64 and text following note 64 .

93 See supra notes 23-25 and accompanying text.

94 Cf. State Purchasing, supra note 5, at 6.6 ("Nonetheless, most state . . . purchasing laws do not provide for the use of competitive negotiation in those cases where the formal sealed competitive bid process is not effective.").

95 See infra notes 140-49 and accompanying text.

96 See infra Appendix II.

97 In particular, officials issue RFPs, or RFPs that are really IFBs, in competitively bid procurements. See, e.g., Transportation Displays, Inc. v. City of 
number of potential competitors may not be economical.98 Maximum effective competition requires removing impediments to effective competitive negotiation. The three basic impediments are collusive drafting of specifications to preclude competitive bidding, ${ }^{89}$ failure to disclose evaluation factors and their weights to all proposers, ${ }^{100}$ and subjective evaluation of proposals. ${ }^{101}$

Among the reasons for these problems is agency failure to clearly distinguish between competitive bidding and competitive negotiation, resulting in courts lacking the proper analytical framework for examining challenges to specific procurements. ${ }^{102}$ The first two problems are largely caused by inadequate statutes and regulations, ${ }^{103}$ and the third by poor implementation of existing statutes and regulations. ${ }^{104}$ Thus, while these problems can be largely mitigated by the substitute legislation proposed in this Comment, the performance of state officials must be carefully monitored to insure that the statute's purpose is being carried out.

This part focuses on these problems by examining the need to identify clearly the chosen method of procurement, the determination when an RFP is to be used, and the selection of appropriate specifications and evaluation factors to be listed in the RFP. The discussion of the problems with the incorrect use of RFPs will focus on the facts of American Totalisator Co. $v$. Seligman ${ }^{105}$ and other appropriate cases. American Totalisator's facts are set forth at some length in order to allow consideration of what procurement

New Orleans, 346 So. 2d 359, 361 (La. Ct. App. 1977) (RFP used in competitive bidding).

88 See supra text accompanying notes 71-74.

89 The need for objective measurable criteria in competitive bidding is analyzed in Crowell \& Chierichella, Source Selection Under the Model Procurement Code, Nat'r Cont. Mamt. Q.J., Third Quarter, 1978, at 17-20. See infra notes 162-65 and accompanying text.

100 See Femino \& Smail, Disclosure of Evaluation Factors and Their Relative Weights: A Continuing Procurement Problem, Nat'L ConT. MGMr. J., Winter $1877-78$, at 15 .

101 See State PuRchasing, supra note 5, at 6.6-.7.

102 See infra notes 112-27 and accompanying text.

103 See supra text accompanying note 95.

104 See supra text accompanying note 28 . It should be noted that there are no cases dealing with recently enacted laws, patterned after the Model Procurement Code, authorizing competitive negotiation. See infra Appendix II. Whether these new statutes will spawn litigation is discussed at infra notes 166-89 and accompanying text.

10534 Pa. Commw. Ct. 391, 384 A.2d 242 (1977) (decree nisi issued), exceptions dismissed per curiam, $34 \mathrm{~Pa}$. Commw. Ct. 436, 384 A.2d 266 (1978) (en banc), aff'd, $489 \mathrm{~Pa} .568,414$ A.2d 1037 (1980); see also $27 \mathrm{~Pa}$. Commw. Ct. B39, 367 A.2d 756 (1976) (preliminary objections overruled). 
method the state used, whether the state could have used competitive bidding properly, what problems a market analysis would have alleviated or eliminated, and whether maximum effective competition was attained.

\section{A. American Totalisator Co. v. Seligman}

American Totalisator involved a challenge to the letting of a public contract for a computerized state lottery system. The Pennsylvania Bureau of State Lotteries invited companies to bid for a contract to develop and implement a daily numbers game. Only two companies, American Totalisator (AmTote) and Control Data Corporation (CDC), submitted bids. After an initial administrative study of the state's needs, an Evaluation Committee was formed. It prepared an RFP, large parts of which were borrowed from an RFP prepared by the state of Maryland for a similar lottery procurement.

The RFP said that the contract would be awarded pursuant to state laws relating to the award of public contracts, and "in conformity with the concept of the lowest responsible bidder." 106 The cover letter sent with the RFP said that Pennsylvania invited companies to participate in a " competitive bidding proposal," " 107 and that bidders would be held to the terms submitted in their proposals.

Both company's proposals met all of the RFP's technical requirements. As the RFP noted, the Committee, using eight categories, reviewed the bidders' technical proposals before the cost proposals were opened and considered. The proposals differed significantly only in that the Committee preferred CDC's computer terminal because it had a cathode ray tube that facilitated clear and efficient operation.

The RFP, possibly anticipating this exact situation, stated that innovative suggestions were encouraged but that " [n]o bid will be disqualified or rejected for failure to submit such suggestions," "108 and that if the Committee liked one proposer's idea, " 'all bidders [would] have an opportunity to conform their proposals in accordance with the revised provisions." 109 AmTote, however, was never given an opportunity to conform its proposal to CDC's sug-

10634 Pa. Commw. Ct. at 396, 384 A.2d at 245.

107 Id.

108 Id. at 399,384 A.2d at 246.

$109 \mathrm{Id}$. 
gestion, although the court found that AmTote could have provided a comparable cathode ray tube. 110

After the Committee finished the technical evaluation, Seligman, the acting Secretary of Revenue, publicly opened the cost proposals. Each bidder thus learned of the other's cost proposal, and it became obvious that "CDC and AmTote had not calculated their bids on the same basis." 111 CDC used an unorthodox method to compute the cost of its proposal, knowing that the state would be unable to ascertain the cost of operating the game. It submitted its proposal in that format so that the state would have to ask for clarification after the bids were opened.

In fact, Seligman did write to each company requesting clarification of its cost proposal. Prior to Seligman's letter, AmTote's bid was definitely lower. But after CDC changed its figures to comport with AmTote's method of calculation, CDC's bid became lower. AmTote was neither told that CDC had computed its cost proposal differently nor given a chance to rebid its cost proposal in light of the change in CDC's bid.

The Committee finally concluded that CDG's bid was lower. For that reason, and because it preferred CDC's terminal with the cathode ray tube, it recommended giving GDG the contract. Seligman relied on the Committee's recommendations in awarding the contract to $\mathrm{CDC}^{112}$

\section{B. The Need to Identify the Procurement Method Clearly}

Part I of this Comment emphasized the differences between competitive negotiation and competitive bidding. A document with detailed specifications-an IFB-is used to initiate competitive bidding, whereas one with more general specifications-an RFPbegins competitive negotiation. ${ }^{113}$ If competitive bidding is used,

$110 \mathrm{Id}$. at $398,384 \mathrm{~A} .2 \mathrm{~d}$ at 246.

111 Id. at $404,384 \mathrm{~A} .2 \mathrm{~d}$ at 248.

$112 \mathrm{Id}$. at $417,384 \mathrm{~A} .2 \mathrm{~d}$ at 256. AmTote brought an action against the Commonwealth to enjoin the contract award and CDC intervened. The commonwealth court found that the Commonwealth breached the terms of its own RFP by not awarding the contract to AmTote, the lowest responsible bidder prior to the "clarification" of proposals. Id. at 435, $384 \mathrm{~A} .2 \mathrm{~d}$ at 265 . The court issued a decree nisi voiding the contract with CDC and ordered the Lottery Bureau to resolicit proposals and competitively bid the contract. Id. at $436,384 \mathrm{~A} .2 \mathrm{~d}$ at 265 .

CDC won the contract following the rebidding. $489 \mathrm{~Pa}$. at 574, $414 \mathrm{A.2d}$ at 1040. AmTote's subsequent appeal was unsuccessful, as the Pennsylvania Supreme Court affirmed the commonwealth court's finding that the RFP initiated competitive bidding. See id. at 575, $414 \mathrm{~A} .2 \mathrm{~d}$ at 1040 .

113 See supra text accompanying notes $41 \& 49-50$ and text following note 41 . 
there can be no discussions between the procuring agency and any offeror. ${ }^{114}$ Each method, then, has its own procedures, ideally formulated so that the use of either will secure maximum effective competition. ${ }^{115}$

In American Totalisator, however, the state gave conflicting signals about what method it was using. Some facts indicated the use of competitive bidding-for example, the RFP's statement that the contract would be awarded "in conformity with the concept of the lowest responsible bidder," "116 and the public opening of bids.117 Other facts pointed toward competitive negotiation-for instance, the use of an RFP rather than an IFB, the discussions with the bidders seeking to clarify the meaning of their bids, 118 and the provisions giving bidders an opportunity to conform their proposals to other bidders' suggestions.110 Finally, there were indications that the state itself was confused, such as the invitation to participate in a "competitive bidding proposal," and the encouragement to submit innovative suggestions with the proviso that no bids would be rejected for failure to do so..$^{120}$

As a result of these conflicting signals, AmTote thought that it was involved in competitive bidding, ${ }^{121}$ while $C D C$ assumed that the agency was using competitive negotiation. ${ }^{122}$ The state increased the confusion by negotiating with CDC, yet not permitting AmTote to change its bid. ${ }^{123}$ This occurred despite the stipulation in the RFP that all bidders would be held to the terms of their proposals. ${ }^{124}$

Thus, American Totalisator illustrates the confusion resulting from purchasing officials' failure to clearly identify the chosen procurement method. It is a serious mistake to initiate competitive bidding with an RPF, ${ }^{125}$ because an RFP indicates to potential contractors that negotiation will be a key phase of the

114 See supra text following note 44.

115 See supra text accompanying and following note 75.

$11834 \mathrm{~Pa}$. Commw. Ct. at 396, 384 A.2d at 245.

$117 \mathrm{Id}$. at $401,384 \mathrm{~A} .2 \mathrm{~d}$ at 247 .

$118 \mathrm{Id}$. at $406-11,384 \mathrm{~A} .2 \mathrm{~d}$ at $250-53$.

119 Id. at 398,384 A.2d at 246.

$120 \mathrm{Id}$. at $399,384 \mathrm{A.2d}$ at 246.

121 See id. at 419, 384 A.2d at 258.

$122489 \mathrm{~Pa}$. at 575 n.5, 414 A.2d at 1040 n.5.

123 See infra notes 133 \& 144 and accompanying text. This problem may be attributed in large part to the state's archaic procurement law. See PA. Stat. ANN. tit. $71, \$ \$ 187,1611-1619$ (Purdon 1962 \& Supp. 1980).

12434 Pa. Commw. Ct. at 396, 384 A.2d at 245.

125 This is particularly the case when the RFP was previously used to conduct a negotiated procurement. See id. at 432, 384 A.2d at 264 (use of the Maryland RFP "unwise"). 
procurement process and that the contract will not be awarded solely on the basis of the lowest price. Initiating competitive bidding with an RFP may mislead bidders into believing that they must submit proposals ${ }^{126}$ that cost more and take longer to prepare than bids. Yet preparing proposals is wasted effort if the only relevant item is cost. ${ }^{127}$ By clearly identifying beforehand which procurement method it is using, the agency avoids imposing needless expense on parties as well as ultimately defending its position in court.

\section{The Advantages of Competitive Negotiation}

Some state laws explicitly permit negotiated procurement; ${ }^{128}$ in other states, courts have interpreted state statutes to permit negotiation ${ }^{128}$ or to allow the state to award a contract to an offeror other than the lowest bidder. ${ }^{130}$ It is important to note, though, that these procedures are inferior to competitive negotiation. The negotiation permitted by these statutes can result in competition among proposers being cut off prematurely, whereas competitive negotiation attempts to maintain competition throughout the procurement process.

\section{Expanding the Concept of Maximum Effective Competition}

In American Totalisator, the state allowed one offeror, CDC, to revise its bid after making each bidder's cost proposals public. ${ }^{181}$ Yet, despite the RFP's representation, ${ }^{132}$ the state did not give AmTote the opportunity to conform its proposal to CDC's by in-

128 See supra text accompanying notes 121-22.

127 An RFP invites the submission of information that will be the basis for later negotiations. But if negotiations are not intended, then preparing the proposals is a waste of the offerors' time and money.

128 See, e.g., Waste Mgmt., Inc. v. Wisconsin Solid Waste Recycling Auth., 84 Wis. 2d 462, 471, 267 N.W.2d 659, 663 (1978).

129 See, e.g., Equitable Shipyards, Inc. v. State, 93 Wash. 2d 465, 473, 611 P.2d 396, 401 (1980). In states where the legal status of a negotiated procurement is in doubt, it is prudent for the procuring agency to seek sole source procurement authorization, see supra note 31 , from the state attorney general prior to negotiating the contract. See, e.g., 1969 Op. Pa. Atty. Gen. No. 285 (authorizing the Commonwealth to negotiate a sole source contract with Westinghouse for specialized equipment needed to operate a water purification plant). This practice, however, completely eliminates competition from the procurement process.

130 See, e.g., State ex rel. E.D.S. Fed. Corp. v. Ginsberg, 259 S.E.2d 618, 625 (W. Va. 1979).

131 See 34 Pa. Commw. Ct. at 406, 409, 384 A.2d at 250, 253.

132 Id. at 399, 432-33, 384 A.2d at 246, 264. 
cluding a cathode tube. This meant that AmTote and GDC were bidding on different specifications, so that AmTote was unable to compete effectively against CDC. Nor was AmTote permitted to rebid its cost proposal when, following clarification, CDC was allowed to change its bid..$^{133}$

These aspects of the case make it clear that the definition of maximum effective competition ${ }^{134}$ must be expanded to include a requirement that procuring agencies should never take any action which will, directly or indirectly, prematurely limit effective competition. By permitting AmTote to conform its proposal to CDC's performance specifications and then to rebid its cost proposal, Pennsylvania could have had effective competition until the actual contract award. Denying Am Tote these opportunities effectively ended competition.

In another case, Waste Management, Inc. v. Wisconsin Solid Waste Recycling Authority, ${ }^{135}$ the state used an RFP in letting a twenty-year contract for the design, construction, and operation of a solid waste recycling facility. ${ }^{136}$ The RFP stated that after the evaluation of proposals, the state would determine a priority list of finalists and commence sequential negotiations with the first preferred proposer. If the state did not reach an agreement with that proposer, it could then begin negotiations with the second preferred

133 Id. at 411,384 A.2d at 253.

134 See supra notes 75-76 and accompanying text.

13584 Wis. $2 \mathrm{~d} 462,267$ N.W.2d 659 (1978).

136 Contracts with architects and engineers are generally considered "professional services," and are exempted by many statutes from competitive bidding. See, e.g., Autotote Itd. v. New Jersey Sports \& Exposition Auth., 85 N.J. 363, 371, 427 A.2d 55, 59 (1981) (contract "constituted 'professional services" within the statutory exception to the requirement of public bidding, N.J.S.A. 5:10-21"); see also.W: KEYES, supra note 32, at 167 ("Under the federal system Architect-Engineer services fall generally under the category of professional and personal services which are to be procured by negotiated procurement").

Federal statutes and regulations provide for an exception to competitive bidding when procuring the services of architects and engineers. See 10 U.S.C. $\$ 4540$, 7212, 9540 (1976 \& Supp. III 1979) (Army, Navy, Air Force respectively); 40 U.S.C. $\$ \$ 41-544$ (1976) (civilian agencies); 40 U.S.C. $\$ 609$ (1976) (General Services Administration); 41 C.F.R. $\$ \$ 1-4.1000$ to -4.1007 ( 1980 ) (civilian); 32 C.F.R. $\$ \$ 18-401$ to -405 (1979) (military). States provide for a similar exception. See Annot., 15 A.L.R.3d 733, 739-42, 746-48 (1967); Slawsky \& DeMarco, Is the Price Right? State and Local Government Architect and Engineer Selection, 40 Pub. ADM. REv. 269-74 (1980).

The Model Procurement Code explicitly addresses architect-engineer contracting. See Model Procurement Code, supra note 12, $\$ 5-101$ to -501 . For an analysis of the Code's treatment of architect-engineer contracting, as well as of state statutes, see Slawsky, The Architect-Engineer Selection Process: To Bid or Not To Bid, 11 Pub. Cont. L.J. 232, 242-49, 255-57 (1979). 
proposer, continuing this process until it reached an agreement with someone on the list. ${ }^{137}$

This procedure also ends competition prematurely. During simultaneous negotiations, the offeror is both negotiating with procurement officials and competing against other offerors who are negotiating with the agency. On the other hand, during sequential negotiations, the offeror's position is more secure. As long as its representatives can come to terms with the state, it will obtain the contract. Lower ranked proposals are considered only if negotiations with higher ranked proposers fail..$^{138}$

If competitive negotiation is selected as the procurement method, then a market analysis will enhance the competitive factors in that process. A market analysis in American Totalisator might have determined the number of potential offerors prior to issuing an RFP; revealed the existence of certain innovations that could have been specified in the original RFP; ascertained the price range for the desired computer lottery system, and increased the detail and precision of specifications in the original RFP. Pennsylvania procurement officials knew that Maryland had earlier procured a similar lottery system and presumably could have obtained some of this information from its state officials. ${ }^{139}$

Maximizing effective competition, then, does not mean always choosing competitive negotiation. It requires the agency to assess the nature of the market for a good or service, determine how firms compete within that market, and tailor the procurement method to take advantage of whatever competition exists for the particular contract.

13784 Wis. $2 d$ at $479-80,267$ N.W.2d at 668.

138 The sequential negotiation technique employed in Waste Mgmt. prevents an agency from choosing a lower ranked proposer who can conform to a higher ranked proposer's innovation at a lower cost. This technique, then, prevents efficient procurement in the sense of minimizing costs.

In State ex rel. E.D.S. Fed. Corp. v. Ginsberg, 259 S.E.2d 618 (W. Va. 1979), a winning proposer included in its proposal a provision violating one of the RFP's requirements. The court dismissed the plaintiff's unresponsiveness argument by noting that this provision was deleted during negotiations. Id. 621, 623. So besides giving proposers the opportunity to conform to other proposals, negotiation allows proposers to conform their proposals to the RFP.

In American Totalisator, CDC was arguably unresponsive to the RFP because it purposefully calculated its cost figures so as to force the state to seek clarification. Competitive negotiations would have prevented CDC from gaining an advantage from its action by permitting AmTote to conform and rebid its proposal. See infra text accompanying notes 143-44 and text following note 144 .

$13934 \mathrm{~Pa}$. Commw. Ct. at 396, 432, 384 A.2d at 245, 264. By drawing on the market analysis and contacting the Maryland agency, Pennsylvania officials could have drafted detailed specifications, issued an IFB, and competitively bid the contract. 


\section{Competitive Negotiation Includes Necessary Safeguards and Guidelines}

When state statutes authorize "negotiation" or courts construe statutes to permit it, procurements become difficult because those statutes rarely contain guidelines and safeguards to ensure the integrity of the procurement process. In Federal Electric Corp. $v$. Fasi, ${ }^{140}$ the Hawaii Supreme Court recognized the need for such safeguards, noting that the city of Honolulu could use an alternative procedure to open bidding "so long as [the] agency has promulgated rules and regulations to insure fair and open competition among bidders." ${ }^{141}$ The court held that "[ $\left.t\right]$ he fact that the procedure was susceptible to abuse and manipulation rendered it illegal." ${ }^{142}$

Another problem that has led to litigation is agency failure to stipulate exactly how it will regulate the final stages of the award process. In Waste Management, the state agency wavered between ordering simultaneous negotation with two finalists and negotiating with the company whose proposal the evaluation committee rated highest. ${ }^{143}$ A regulation requiring simultaneous negotiation, or one allowing negotiation with one company only after a certain stage in the award process, would have cured this problem.

Regulations could also have eliminated the problem in American Totalisator, in which the process became unfair when the state permitted one company to rebid its cost proposal after the bids were opened publicly without permitting the other company to do likewise. ${ }^{144}$ Either the bids should not have been publicly disclosed and the procuring agency should have entered into negotiations with both proposers, or no rebidding should have been permitted.

In State ex rel. E.D.S. Federal Corp. v. Ginsberg, ${ }^{145}$ it was argued that the state had permitted one of the proposers to remove, during negotiations, a provision in its proposal that violated an

14056 Hawaii 57, 527 P.2d 1284 (1974). The city of Honolulu attempted to procure a sophisticated police communications system using what the Hawaii Supreme Court called the "request for proposal" method." Id. at 59, 527 P.2d at 1287. This was the first time the city had used an RFP, and no regulations governed such a procurement. The procurement was similar to the two-step formal advertising method, see supra note 31 , but the court ruled that the city had prevented offerors from competing fairly by combining the two steps. Id. at 60,62 , 527 P.2d at 1288.

141 Id. at $61,527 \mathrm{P} .2 \mathrm{~d}$ at 1288.

142 Id. at 62,527 P.2d at 1289 (citations omitted).

14384 Wis. $2 d$ at $481-86,267$ N.W.2d at $669-71$.

$14434 \mathrm{~Pa}$. Commw. Ct. at 409-11, 384 A.2d at 251-53.

145259 S.E.2d 618 (W. Va. 1979). 
RFP requirement. ${ }^{148}$ Although the court held that the state's action was legal, ${ }^{147}$ a regulation either requiring absolute responsiveness ${ }^{\mathbf{1 4 8}}$ or allowing unresponsive proposals to be "cured" during negotiation would have avoided this lawsuit.

These cases make apparent the recurring judicial and administrative confusion resulting from attempts to purchase unusual goods using antiquated competitive bidding statutes. Yet most of that confusion would have been avoided had the agency, using its statutory authority, promulgated regulations prior to any procurement. In the absence of such regulations, state negotiated procurements are rarely competitive and all too often unfair. ${ }^{149}$

\section{Specifications and Evaluation Factors}

1. Specifications: Detailed or Indefinite?

If specifications in an RFP are too detailed, a potential proposer may argue that the procurement agency drafted the specifications so narrowly that only one company could submit a proposal. In BusTop Shelters, Inc. v. City of New York, ${ }^{150}$ the plaintiff had been the city's sole franchisee for bus stop shelter construction. The city decided to award a long term contract, and issued an RFP with a security requirement for applicants signficantly higher than that originally demanded from the plaintiff. BusTop alleged that this increased security deposit " 'resulted from a desire on the part of the Comptroller's Office to construct a sweetheart contract for a competitor company of BusTop which the Comptroller knew could easily meet such enormously inflated security demands.'" 151 The court held that the city was simply acting to obtain the best terms possible for itself, and this ruling appears justified because the petitioner lacked proof of favoritism. But it is apparent that drawing narrow specifications is a relatively simple collusive method of lessening competition.

On the other hand, specifications in an RFP can be too indefinite. This also presents the possibility of collusion, because a pro-

146 Id. $621,625$.

147 Id. 625.

148 See supra note 47.

149 See, e.g., International Telecommunications Systems v. State, 359 So. 2d 364, 367 (Ala. 1978); Fasi, 56 Hawaii at 61, 63, 66, 527 P.2d at 1287, 1288, 1289.

10099 Misc. 2d 198, 415 N.Y.S.2d 726 (Sup. Ct. 1978).

$101 \mathrm{Id}$. at 201, 415 N.Y.S.2d at 729 (emphasis in original). Furthermore, the petitioner claimed that the city "undertook no studies to warrant the security ... terms of the RFP." Id. 
curement official can lay out vague enough specifications to call one company's proposal "responsive" and eliminate competing proposals as unresponsive. ${ }^{152}$ Indefinite specifications also tend to confuse potential offerors, who may be unsure what the agency seeks to procure.

Treading the fine line between too definite and too vague is not easy. ${ }^{153}$ The problem, though, can be addressed in several ways. For example, although RFPs in competitively negotiated procurement are inevitably rather indefinite, ${ }^{154}$ a market analysis should help to make them as concrete as possible. ${ }^{155}$

\section{Evaluation Factors: Disclosed or Concealed?}

RFPs usually list the criteria by which the procuring agency will evaluate proposals. The first question that has arisen is whether the official must use all of the criteria listed or may base a decision on only some of them. The second is whether the procurement official may use criteria other than those listed.

The first problem arose in Equitable Shipyards, Inc. $v$. State. ${ }^{156}$ The appellant argued that a particular factor, life cycle costs, should not have been used in evaluating its proposal. The court noted that the appellant was disregarding the language of the contract award statute, and added that the proposer knew the state's statutory construction because it was set forth in the RFP. ${ }^{157}$ This was the only principled decision the court could have made, for allowing procurement officials to pick and choose among evaluation criteria listed

152 In a somewhat similar case involving litigation over the use of an indefinite RFP in a competitively bid procurement, the court noted that "the combination of open specifications and the statement in the RFP that the [agency] could assign various weights to the eighteen evaluation criteria freed the [agency] to select any bidder it desired without reference to specific detailed guidelines." Datatrol Inc. v. State Purchasing Agent, 80 Mass. Adv. Sh. 299, - n.5, 400 N.E.2d 1218, 1223. n.5 (1980). The court also said that "the need for definiteness may even increase when criteria other than price come into play and awards based on favoritism become harder to detect." Id. at $\longrightarrow, 400$ N.E.2d at 1230 (footnote omitted).

153 Of course, if competitive bidding is chosen as the appropriate procurement method, specifications must be as detailed as possible. See stpra notes $41-43$ and accompanying text.

154 See supra notes 50-53 and accompanying text. Cf. State ex rel. E.D.S. Fed. Corp. v. Ginsberg, 259 S.E.2d 618, 624 (W. Va. 1979) ("It was contemplated in the Request For Proposal that the solution might very well entail a redefinition of the problem").

155 Performance of a market analysis would also indicate that specifications were developed objectively and not as a result of collusion or favoritism. See supra note 151 and accompanying text.

15093 Wash. $2 d$ 465, 611 P.2d 396 (1980).

167 Id. at 483,611 P.2d at $406-07$. 
in the RFP would invite abuse. The official could make almost any proposal look outstanding by emphasizing certain criteria that it satisfied.

As for the second problem, allowing officials to use criteria not set forth in an RFP also encourages abuse. In In re Honeywell Information Systems, Inc. Protest of Contract Award Requisition $X-32,{ }^{158}$ the court broadly construed a New Jersey statute authorizing the state to award contracts to bidders whose bids "will be most advantageous to the State, price and other factors considered." 159 The court interpreted these words to mean that a procurement official could resort to evaluative criteria not listed in the RFP..$^{160}$

This result stifles competition because potential proposers do not know the bases for evaluation of their proposals; thus, drafting proposals becomes very difficult. Both of these problems with evaluation criteria can be eliminated by the passage of state laws that require all evaluation factors to be fully disclosed in the RFP and used in toto. ${ }^{161}$

Another problem related to disclosure of evaluation factors is whether these factors' weights should be disclosed. ${ }^{162}$ Nondisclosure

158145 N.J. Super. 187, 367 A.2d 432 (1976), certification denied, 73 N.J. 53, 372 A.2d 318 (1977).

169 Id. at 199, 367 A.2d at 438 (quoting N.J. Stat. ANN. $\$ 52: 34-12$ (d) (West 1955)) (emphasis added). The statute was subsequently amended. See N.J. Stat. ANn. $§ 52: 34-12$ (d) (West Supp. 1981).

100145 N.J. Super. at 199-200, 367 A.2d at 438-39. The court could have also interpreted the statute to mean that RFPs can set forth evaluative criteria in addition to price, but that procurement decisions must be based only on those criteria.

In Honeywell, the court permitted the state to consider one proposer's "purchase option credits" resulting from a preexisting contract with the state. Without those credits, this proposal was not the lowest priced bid; with them, it was the winning proposal. Id. at 194-95, $367 \mathrm{~A} .2 \mathrm{~d}$ at 436 . The court later acknowledged that "it would have been preferable practice under the existing circumstances to have made some reference in the RFP to the possibility that purchase option credits would be considered in evaluating the proposals." Id. at 205, 367 A.2d at 442 .

161 Careful drafting of RFPs can also solve potential problems in the evaluation process. In a recent New York case, the state Department of Taxation and Finance issued an RFP for a contract to supply and operate an on-line computerized state lottery system. The RFP provided that alternative technical specifications would be taken into consideration in the event of a tie during the evaluation process. The New York court upheld the use of this tie-breaking provision because it was disclosed as a possible evaluation factor in the original RFP. See American Totalisator Co. v. New York State Dep't of Taxation \& Fin., 80 A.D.2d 373, 439 N.Y.S.2d 732 (1981).

162 See Femino \& Smail, Disclosure of Evaluation Factors and Their Relative Weights: A Continuing Procurement Problem, NAT'L Cont. MGMr. J., Winter 1977-78, at 15 (concerning federal procurement, but analysis is equally applicable to state contracting).

Besides disclosing relative weights, procurement offcials should, whenever possible, evaluate proposals using "objective measurable criteria." Objective criteria 
of weights increases flexibility in the evaluation process, ${ }^{163}$ but at the risk of arbitrariness and subjectivity. Disclosing weights fosters effective competition by preventing offerors who are good guessers or who have dealt with the contracting agency in the past from gaining an advantage. ${ }^{184}$ Disclosure may also reduce the number and effectiveness of contested contract awards. ${ }^{165}$

This part has examined state case law on RFPs and has pointed out the need for legislative remedies to redress problems arising from a fundamental misunderstanding of RFPs and IFBs; the hesitancy or unwillingness to ascertain market conditions prior to selecting an appropriate procurement method, and the subjective determination of specifications and evaluation factors. Part III assesses the first comprehensive effort at legislative reform of state procurement laws and regulations.

\section{The Model Procurement Code}

\section{A. A Critical First Step}

In February 1979, the House of Delegates of the American Bar Association (ABA) ratified and offered to the states for enactment a

will generally be more relevant to competitive bidding than to competitive negotiation. See Crowell \& Chierichella, Source Selection Under the Model Procurement Code, Nat'x Conx. Mamt. Q.J., Sept. 1978, at 13, 16-17.

163 See Femino \& Smail, supra note 162, at 15. Cf. Datatrol, 80 Mass. Adv. Sh. at -, 400 N.E.2d at $1222-23$ \& 1223 n.5 (example of nondisclosure of relative weights in an RFP). Some commentators argue that disclosure of numerical weights does not limit agency discretion in procurement. Femino \& Smail, supra note 162, at 21-22.

184 When disclosure of numerical weights is prohibited, "procuring agencies using numerical evaluation plans must subjectively convert the numbers into some narrative expression" in the RFP. "Because the narrative language used varies widely [between procurements], those offerors most familiar with the past practices of a contracting office have a competitive edge." Femino \& Smail, supra note 162, at 21. "Since 1962, the Comptroller General has repeatedly stated that sound procurement policy requires the disclosure of relative weights attached to evaluation factors ...." Id.

165 Id. 21. Although this Comment focuses on disclosure during the RFP stage of a procurement, written disclosure after procurement of the criteria the agency relied upon in awarding a contract will greatly aid judicial review of that procurement. See E.D.S. Federal, 259 S.E.2d at 626.

There are other ways of avoiding collusion and favoritism. For example, procuring agencies might require submission of price and technical proposals in separate envelopes. The evaluation committee could then consider the technical proposals separate from the price proposals. This method would ensure that each proposal is initially judged on its merits. Or, the agency might disguise the identity of proposers to prevent subjective judgments and intentional favoritism. See Nash \& Love, supra note 18, at 332 n.49. Both the federal and state governments have successfully used this approach. See, e.g., Sun Ship, Inc. v. Woolsey, 484 F. Supp. 1348, 1350-51 (D.D.C. 1979); E.D.S. Federal, 259 S.E.2d at 622. 
"blueprint for improving public procurement." ${ }^{16 \varepsilon}$ The Model Procurement Code for State and Local Governments culminates an exhaustive five year effort to provide a sound legislative foundation upon which states "can build and operate a modern and efficient purchasing system." 187

The Model Procurement Code emphasizes certain fundamental policies ${ }^{188}$ that, if followed by state governments, would undoubtedly improve many archaic procurement systems. Some of the more advantageous policies include centralizing the award and administration of public contracts, ${ }^{109}$ establishing comprehensive and efficient conflict resolution procedures, ${ }^{170}$ and providing ethical standards to govern public and private participants in the procurement process. ${ }^{171}$ These improvements will enhance the integrity and accountability of the state procurement decisionmaking processes, and will maximize the purchasing value of public funds.

The Model Procurement Code also authorizes the use of RFPs in a procedure, similar to competitive negotiation, referred to as "Competitive Sealed Proposals." 172 By recognizing the need for a procurement method other than competitive bidding, ${ }^{173}$ the. Code represents a significant improvement upon state purchasing laws authorizing only competitive bidding. The "competitive sealed proposals" provision, however, contains several serious weaknesses that, if left uncorrected, could result in allowing the negotiated procurement exception to swallow the rule of competitive bidding.

\section{B. A Critique of the "Practicable-Advantageous" Standard}

A fundamental flaw in the Model Procurement Code's process of "competitive sealed proposals" is the standard used to invoke that

166 Hiestand, supra note 10, at 6.

167 Press release by William Montalto, Project Director, Model Procurement Code Project, $A B A$ Approves a Model Procurement Code for State and Local Governments (1979) (on file with the University of Pennsylvania Law Review). Recognizing the diversity of existing state procurement structures and needs, the drafters developed a "model" rather than a "uniform" code. MoDex ProcureMENT CODE, supra note 12, at vii ("varying organizational and political constraints in enacting jurisdictions might require the adaptation of any proposed code to particular state and local situations").

168 Model Procunement Code, supta note 12, \$1-101(2).

160 Id. $\$ \$ 2-101,-102,-201,-204,-301$.

170 Id. $\$ \$ 9-101,-103,-201$ to -203 .

171 Id. $\$ \$ 12-201$ to -209 . See $i d$. $\$ \$ 12-301$ to $-302,-401$ (enforcement provisions).

172 Id. $\$ 3-203$.

173 Sealed competitive bidding is clearly established as the preferred procurement method. See id. $\$ \$ 3-202(1)$ commentary (2); 3-203 commentary (1). See generally id. \$ 3-203 commentary (3). 
procurement method. That standard permits the procurement officer who "determines in writing that the use of competitive sealed bidding is either not practicable or not advantageous to the [State]" 174 to contract by using RFPs and negotiations. ${ }^{175}$ The "practicable-advantageous" standard is very broad, and the statute contains no clarification or qualification other than a reference to "regulations promulgated by the Policy Office." 176

The ABA's commentary offers some guidance in discerning the meaning of the standard by including illustrations of how an official might determine whether bidding is practicable or advantageous. A particularly helpful one is "whether the marketplace will respond better to a solicitation permitting not only a range of alternative proposals but evaluation and discussion of them before making the award." 177 But this is the Code's only reference to market conditions in connection with the decision to use RFPs, and it is not included in the statute.

The "practicable-advantageous" standard is very similar to the "feasible-practicable" standard adopted in federal procurements. 178 Both the federal and ABA Code standards fail to state what conditions the purchasing officer should consider before deciding which procurement method to employ, and neither standard explicitly states that a market analysis must be performed prior to determining the appropriate procurement method. Consequently, under both

174 Id., $\$ 3-203(1)$. See supra note 16.

175 Model Procurement Code, supra note 12 , \$\$3-203(2), -203(6).

176 Id. $\$ 3-203(1)$. The ABA approved a voluminous set of "Recommended Regulations" to accompany the Model Procurement Code on August 2, 1980. The Code by design relies to a considerable extent on these supplementary regulations because they afford the Code flexibility and enable it to evolve as procurement experience and governmental needs change. See id. vii. The need for flexibility does not, however, justify the use of vague standards to guide critical decisions, and the regulations' major shortcoming is that they fail to clarify the "practicableadvantageous" standard. See Coordinating Commitree on a Model Procurement CODE For State and LOCAL GOVERNMENTS, RECOMMENDED Regulations R3-203.02.3 (practicable), R3-203.02.4 (advantageous) (1980). Furthermore, only the first commentary accompanying the regulations suggests any procedure even resembling a market analysis. See id. R3-203.02.4 commentary (I).

177 Moder Procurement Code, supra note 12, \$3-203(1) commentary (4)(d).

178 See supra note 88 and text accompanying notes 86-93 (critique of the "feasible-practicable" standard). The Code states that competitive negotiations may be used when competitive bidding is "either not practicable or not advantageous." MODEx PRocurEmENT CODE, supra note $12, \$ 3-203(1)$. The official commentary notes that "both terms are used ... to avoid a possible restrictive interpretation of the authority to use competitive sealed proposals." Id. $\$ 3-203$ commentary (4). Thus, the Code's language enables an agency to choose competitive negotiation just as easily as it could under federal regulations, which mandate competitive bidding only where it is both "feasible and practicable," see supra note 86 , allowing competitive negotiation to be chosen too easily. See supra note 88 and accompanying text. 
standards, the scope of discretion afforded a procurement officer is effectively limitless. ${ }^{179}$

The difficulty of designing a workable standard is demonstrated by considering the two rough drafts of the Code. Each draft contained a different formulation of the standard for determining the appropriate procurement method. Preliminary Working Paper Number One incorporated the federal government standard of feasibility or practicability. 180 Preliminary Working Paper Number Two dropped feasibility from the standard and authorized competitive negotiations whenever competitive sealed bidding was not "practicable." 181 This formulation was fairly rigorous in terms of enforcing the statutory preference for competitive bidding, but was still vague and was not tied to an analysis of market conditions.

\section{Other Criticisms}

Two other weaknesses hamper the effectiveness of the Code's "competitive sealed proposals" provision. First, the Code defines IFBs as "all documents ... utilized for soliciting bids," and RFPs as "all documents . . . utilized for soliciting proposals." 182 .These definitions are identical except for the words "bids" and "proposals." Yet a proper substantive definition of the RFP should recognize that the document is the beginning of a process contemplating negotiations to clarify proposals prior to a contract award. This definition would help prevent confusion between the two types of procurement. For the same reason, the definition should emphasize that the RFP is a request, not an offer, and that the issuer of the RFP can change or withdraw the document prior to the contract award. ${ }^{183}$ In contrast, the IFB cannot, absent unusual circumstances, be changed or withdrawn after issuance. ${ }^{184}$

179 of course, this discretion is limited by the federal regulations or the recommended Model Procurement Code regulations. But it is clear that no law limits a procurement official's discretion. Because a state may adopt the Model Procurement Code without necessarily promulgating the recommended regulations, the "practical-advantageous" standard may stand without qualification.

180 Coordinating Committee on a Model Procurement Code for State and Local Governments, Preliminary Working Paper No. 1, §2-105(1) (June 25, 1976). But the commentary following $\$ 2-105$ indicates a desire not to duplicate the competitive bidding exemptions in the federal regulations, stating that the statute does not attempt to establish "a litany of descriptive circumstances that might justify [competitive negotiation]." The Committee believed that "any such illustrative listing . . . would not be appropriate." Id. \$2-105 commentary (2).

181 Coordinating Committee on a Model Procurement Code for State and Local Governments, Preliminary Working Paper No. 2, $\$ 3-203(1)$ (June 13, 1977). 182 See Moder Procurement Code, supra note 12, \$\$3-101(3), -101(5).

183 L. Benowich, Damages Liability in RFP Situations 3 (June 27, 1980) (unpublished memorandum for the Corporation Counsel of New York City) (on file with the University of Pennsylvania Law Review).

184 See, e.g., 41 C.F.R. $\$ 1-2.404-1$ (1980). 
The second weakness is that the Model Procurement Code does not require use and full disclosure of objective measurable criteria in evaluating proposals. Although the Code provides for the disclosure of "the relative importance of price and other evaluation factors" in the RFP, ${ }^{185}$ and limits the evaluation process to those listed factors, ${ }^{180}$ the drafters did not read these provisions to require disclosure of specific numerical weights. ${ }^{187}$ In light of the need to maximize competition, this approach seems insufficient. There is no adequate justification for the refusal to disclose "specific numerical weightings" if the procurement officer contemplates using them. ${ }^{188}$

Furthermore, a statute that seeks the optimum benefits from a competitive solicitation must require that only objective measurable criteria be used in evaluating awards. Each factor should be assigned an absolute weight and listed in the RFP to indicate its specific evaluative significance to all proposers. For example, if an official will rate the proposals to some extent on their degree of innovation, proposers should know how much weight that criterion will carry. If it is $20 \%$, the potential proposer will spend less time designing innovations than if that factor will account for $50 \%$ of the total evaluation. If it is not possible to determine a factor's weight when an RFP is initially drafted, then it should be made known to all offerors before the procurement officer accepts "best and final offers." 188

In sum, the Model Procurement Code represents a critical first step for states contemplating its adoption. Many of its provisions will provide a sound legislative foundation for an effective procurement system. But wholesale adoption of the Code's "competitive" sealed proposals" provisions may result in a faltering first step. This is so because the Code provisions increasing the discretion of procurement officials to elect the use of.RFPs instead of IFBs place the statutory preference for competitive bidding in jeopardy. Also, the provisions do not clarify the difference between the two procurement methods, and do not require objectivity in evaluating proposals. The effectiveness of these Model Procurement Code provisions is, therefore, subject to doubt.

186 Moder Procurement Code, supta note 12, $\$ 3-203(5)$.

188 Id. \$3-203(7).

187 Id. $\S 3-203(5)$ commentary.

188.The Code provisions only partially redress the problem discussed at supra text accompanying notes 162-65.

189 "Best and final offers" or "proposals" is included in the Model Procurement Code, $\$ 3-203(6)$, and in the federal regulations. See 32 C.F.R. $\$ 3-805.3$ (d) (1979). But see 41 C.F.R. $\$ 1-3.805-1$ (b) (1980). The call for "best and final offers" indicates that the negotiation process is over and that a final offer must be submitted without further discussions. 


\section{Proposed Legislation: A Comparattve ANalysis}

Because of the current problems of state procurement and the weaknesses in the Model Procurement Code, this Comment suggests a statutory substitute for the Code's section 3-203 ("competitive sealed proposals"), consisting of a definitions section and a replacement for section 3-203. This substitute, set forth in Appendix I, will preserve the statutory preference for competitive bidding in most state statutes and in the Model Code, and will make procurement more efficient when competitive negotiation is used.

The first subsection in section 3-203, "conditions for use," replaces the vague "practicable-advantageous" standard. This requirement seeks maximum effective competition, which the substitute legislation defines at length. ${ }^{190}$ Because the definition of maximum effective competition contains several procedural safeguards, ${ }^{101}$ it will be less susceptible to abuse than the practicable-advantageous standard.

By its terms, the substitute section makes the presumption in favor of competitive bidding ${ }^{192}$ difficult to overcome. First, the agency must conduct a market analysis focusing on whether the procurement need can be articulated specifically enough to enable a reasonable number of suppliers to bid for the contract without needing agency clarification of any matter relating to the procurement. Second, the agency must reduce that analysis, ${ }^{193}$ along with any decision not to use competitive bidding, ${ }^{194}$ to writing. This will enable a reviewing court to better judge whether the procuring agency abused its statutory discretion in choosing competitive negotiation. ${ }^{198}$

The substitute legislation also includes a safeguard against the collusive drafting of specifications alleged in BusTop Shelters, Inc. v. City of New York. ${ }^{198}$ New York City could have asked offerors how large a security bond they would be willing to post, making the bond a part of the proposals. Instead, the city re-

190 See infra Appendix I (\$3-101(5) of the Proposed Substitute Legislation) [hereinafter cited as Substitute].

191 See infra Appendix I (Substitute $\$ 3-101(5)(a)-(b))$.

192 See infra Appendix I (Substitute \$3-203(1)).

193 See infra Appendix I (Substitute \$3-101(4)).

194 See infra Appendix I (Substitute \$3-203(1)).

105 By design, however, the standard of maximum effective competition creates a strong presumption in favor of competitive bidding, leaving an agency with little discretion in its choice of procurement method. See infra Appendix I (Substitute $\$ 3-101(5))$.

10099 Misc. $2 d$ 198, 415 N.Y.S.2d 726 (Sup. Ct. 1978). See supra text following note 149 and accompanying notes $150-51$. 
quired a minimum bond as a prerequisite to responding to itsRFP. The proposed legislation would treat such items as specifications, ${ }^{197}$ and would require those specifications to be drafted after a market analysis had been performed and the procurement method chosen. ${ }^{198}$ So an agency, trying to defend its specifications against a legal challenge, would have to show that a market study indicated the existence of articulable reasons for the specifications chosen.

The Code's definition of an RFP was faulted earlier for its superficiality. The suggested substitute clarifies the definition by requiring an RFP to meet three conditions. First, an RFP will have to inform potential proposers that discussions will be an integral part of the procurement process. ${ }^{199}$ Second, the RFP will have to indicate that "the contract will not necessarily be awarded on the basis of lowest price." 200 Third, the RFP will have to disclose all the criteria, together with their absolute weights, that the agency will use to evaluate proposals. ${ }^{201}$

The inclusion of this third element in the RFP in In Re Honeywell Information Systems, Inc. Protest of Contract Award Requisition $X-32{ }^{202}$ would have prevented the state procurement agency from considering as an evaluation factor the "purchase option credits" that. one of the proposers had used in dealing with other state agencies prior to the issuance of the RFP. This would have prevented that proposer from having a considerable cost advantage, thereby eliminating the basis of the resulting lawsuit. Similarly, if the state in Equitable Shipyards, Inc. $v$. State ${ }^{203}$ had clearly indicated in its RFP that all the listed criteria would be used to evaluate proposals, there could have been no argument that life cycle costs should not have been used to evaluate submissions.

The proposed legislation also explicitly provides for the modification and withdrawal of an RFP. ${ }^{204}$ Thus, in Honeywell, after the

197 See infra Appendix I (Substitute $\$ 3-101(7)$ ).

198 See infra Appendix I (Substitute $\$ 3-203(1)$ ). Because one purpose of the market analysis is to develop specifications, and specifications include the required qualifications for potential contractors, the market analysis must define the minimum qualifications necessary to obtain responsible offerors. Any standards more restrictive than this minimum level prevent offerors able to perform the contract from responding to an RFP.

199 See infra Appendix I (Substitute $\$ 3-101(8)(a))$.

200 See infra Appendix I (Substitute $\$ 3-101(8)(\mathrm{c})$ ).

201 See infra Appendix I (Substitute $\$ 3-101(8)(d)$ ). The Model Code does not contain these or any similar requirements. See MOder Procurement Code, supra note $12, \$ 3-101(5)$.

202145 N.J. Super. 187, 367 A.2d 432 (1976), certification denied, 73 N.J. 53, 372 A.2d 318 (1977). See supra notes $158-61$ and accompanying text.

20393 Wash. $2 \mathrm{~d} 465,611$ P.2d 396 (1980). See supra text accompanying notes $156-57$.

204 See infra Appendix I (Substitute $\$ 3-203(2)$ ). 
state realized that one of the proposers wanted to make use of its preexisting "purchase option credits" to decrease its cost proposal, the state could have modified its RFP to include the availability of those credits as one of its evaluation criteria. Then the competing proposer could not have complained that the state used an undisclosed evaluation factor.

Proposed section 3-203(6) rectifies another problem, the unfair advantages given to CDC in the American Totalisator Co. v. Selig$\operatorname{man}^{205}$ procurement. That section requires "fair and equal treatment" of offerors "with respect to any opportunity for discussion and revision of proposals." 208 The section would have also helped to eliminate the question litigated in Waste Management, Inc. $v$. Wisconsin Solid Waste Recycling Authority, ${ }^{207}$ in which the state kept wavering between using simultaneous and sequential negotiations. Simultaneous discussions with the various proposers, ending when the agency called for "best and final proposals," 208 would have rendered the procedure completely unambiguous.

Recognizing that competitive negotiation may not be costjustified for the procurement of low-cost goods and services, the proposed substitute also sets a minimum dollar amount for any competitively negotiated procurement. Below that amount, an agency may not use competitive negotiation. Because allowing an agency to change the cutoff would be administratively unfeasible, state legislatures must choose an amount appropriate to the state's size, the number and dollar amount of typical procurements, and the cost of preparing and responding to an RFP. ${ }^{209}$

Finally, the proposed legislation's requirement that "objective measurable criteria" be used to evaluate proposals is a significant departure from the Model Procurement Code. ${ }^{210}$ Whereas the Code notes that "[s]pecific numerical weighting is not required," 211 the substitute provision, in its definition of objective measurable criteria, stipulates that a "listing of criteria in order of their relative im-

$20534 \mathrm{~Pa}$. Commw. Ct. 391, 384 A.2d 242 (1977), exceptions dismissed per curiam, $34 \mathrm{~Pa}$. Commw. Ct. 436, 384 A.2d 266 (1978) (en banc), aff'd, $489 \mathrm{~Pa}$. 568, 414 A.2d 1037 (1980). See supra text accompanying notes 109 \& 123-24.

206 See infra Appendix I (Substitute \$3-203(6)). This section closely tracks the language of the Code proposal. See Model Procurement Code, supra note $12, \$ 3-203(6)$ and accompanying commentary.

20784 Wis. $2 d 462,267$ N.W.2d 659 (1978). See supra text accompanying notes 135-37 \& 143.

208 See infra Appendix I (Substitute $\$ 3-101(1))$.

200 See infra Appendix I (Substitute $\$ 3-203(2)$ ).

210 Compare infra Appendix I (Substitute \$3-203(5)) with MODEx ProCOREMERT CODE, supra note $12, \S 3-203(5)$ and accompanying commentary.

211 Moder Procurement Code, supra note 12, \$3-203(5) commentary. 
portance" is insufficient. ${ }^{212}$ As discussed earlier, disclosure of these weights may limit flexibility in procurement, but this detriment is outweighed by the benefits of increased equity and smaller chance of legal challenges.

\section{Conclusion}

State and local procurement expenditures have been growing steadily since 1970, and will exceed those of the federal government by an estimated $\$ 138$ billion in $1981 .{ }^{213}$ The potential gain from the enormous dollar volume of state procurement spending depends largely upon how these procurements are contracted for and administered.

Few benefits and much waste will result if procurement expenditures continue to be governed by state laws dating from the Depression. These laws do not take account of significant changes in economic conditions that have occurred during the last fifty years, particularly the increasing technological sophistication of procured goods and services. These changes require an alternative to the competitive bidding method favored by the drafters of purchasing laws in the first third of the century. This Comment has explored that alternative-competitive negotiation, the problems arising from its present use by states, and the need for legislation to secure the benefits that states and their citizens can obtain from its effective use.

212 See infra Appendix I (Substitute $\$ 3-101(6)$ ).

213 Corrant Business, supra note $I_{2}$ at 8. 


\section{Appendrx 1}

Proposed Legislation for Competrtive Negotiation

\section{\$3-101 Definitions OF Terms}

(1) Best and Final Proposal-the last proposal submitted by an offeror, upon which a decision for contract award is based. No discussions between procurement officers and proposers may occur from the time a call for "best and final proposals" is made to the time of contract award, nor may any terms in a proposal be changed during that time. ${ }^{214}$

(2) Competitive Negotiation-a government procurement process, initiated by a "Request for Proposals," which permits discussions between the procuring agency and proposers. When a contract is let by "competitive negotiation," the price submitted in the proposal is not the exclusive factor upon which the contract is awarded. ${ }^{215}$

(3) Discussions-nonbinding negotiations between the procuring agency and a proposer. These negotiations are confidential; the agency may not reveal the contents of any proposal or any matter discussed. Discussions may be used to clarify ambiguities in proposals, fill in omissions, add to and correct specifications, determine production capabilities of proposers, and determine ranges of quality and costs. This listing does not imply the exclusion of subjects not listed herein. ${ }^{216}$

(4) Market Analysis-an in-depth study of the competitive forces in the particular market for the goods or services sought by the government procurement agency. A market analysis is used to determine which method of procurement is most appropriate. "Competitive forces" include but are not limited to the range of quality available in the market; the technological sophistication of the procurement need; the degree to which the procurement agency can specify the goods and services it seeks; the frequency of similar purchases by other government agencies, either within or without that jurisdiction; the number of potential proposers; the expense of preparing a proposal; the possibility of collusion among potential proposers, and the degree to which proposers can compete solely on the basis of price. This analysis must be written and retained by

214 See supra note 189 \& text accompanying notes 207-208.

215 See supra text accompanying notes 17-21 \& 49-61.

216 See supra text accompanying notes 54-55 and text following note 137 . 
the agency for a period of not less than one year more than the statute of limitations applicable to challenges to the procurement. It must also be available for public inspection..$^{217}$

(5) Maximum Effective Competition (MEC)-the ultimate goal of any procurement, to be achieved by using the competitive forces within a particular market to obtain, in terms of both price and quality, the best overall good or service. Where the desired item is readily available in the market at the desired level of quality, and can be clearly and accurately specified, MEG can best be attained through the use of competitive bidding. Where price, quality, and design of a desired item vary greatly in the market, and detailed specifications can be provided only after discussions, MEC is best attained by competitive negotiation. The performance of a market analysis will provide the information necessary to determine which type of market the procuring agency faces.

As long as the procurement is publicly advertised, there is no absolute duty to solicit every possible offeror for proposals. The agency should increase the number of competing proposers only to the extent that competition is effective to procure its needs.

Other aspects of MEC, with respect to competitive negotiation, include the following:

(a) the agency must promulgate regulations detailing the procedures to be followed in a competitively negotiated procurement;

(b) these regulations should, at a minimum, guarantee that:

(i) specifications in the RFP will be sufficiently detailed to give a proposer notice of what the agency is seeking to procure. But specifications should not be drafted so narrowly that they effectively limit competition at some intermediate stage of the procurement;

(ii) the market analysis will state how the agency chose the specifications used in the RFP;

(iii) no action will be taken which will, directly or indirectly, prematurely limit effective competition;

(iv) prior to the call for best and final proposals an agency will negotiate simultaneously, rather than sequentially, with proposers; and, 
(v) prior to the call for best and final proposals, all parties may conform their proposal to the performance specifications made in a competitor's proposal. ${ }^{218}$

(6) Objective Measurable Criteria-specific numerical weightings which indicate the degree to which each evaluation factor will be considered in a procurement decision. A listing of criteria in order of their relative importance does not meet this requirement. 219

(7) Purchase Description-the words used in a solicitation to describe the goods or services to be purchased, including the specifications attached to or made a part of the solicitation. Specifications are a description of the design and performance of the good or service to be procured. In addition, specifications must include requirements, if any, that proposers must meet in order to be considered responsible proposers.220

(8) Request for Proposals (RFP)-all documents, whether attached or incorporated by reference, utilized to initiate a solicitation for proposals for a competitively negotiated procurement. The RFP must include, but is not limited to, the following:

(a) a description of the competitive negotiation procedures to be used and relevant statutory and regulatory references;

(b) specifications of the good or service desired;

(c) a statement explicitly declaring that the contract will not necessarily be awarded on the basis of lowest price; and,

(d) a complete list, together with absolute weights, of the criteria the agency will use to evaluate proposals.221

(9) Responsible Offeror-a person who has the capability in all respects to fully perform the contract requirements, and the integrity and reliability which will assure good faith performance. ${ }^{222}$

\section{§3-203 Competitive Negotiation}

(1) Conditions for Use When, under regulations promulgated by the Policy Office, the Chief Procurement Officer or Head of a

218 See supra text accompanying notes 71-77, 98-101, 134-38, 140-49 and text following note 139.

210 See supra text accompanying note 100.

220 See supra notes 41 \& 149-50 and accompanying text; supra notes 151-55.

221 See supra text accompanying notes $49-61$.

222 See supra note 46. 
Purchasing Agency determines in writing that the use of competitive sealed bidding will not attain maximum effective competition for a particular purchase, a contract may be entered into by competitive negotiation. No determination to use competitive negotiation can be made prior to the Chief Procurement Officer or a designee conducting a market anlysis. Specifications for a purchase description shall be drafted after an appropriate procurement method has been selected.

(2) Request for Proposals The Request for Proposals initiates competitive negotiation and emphasizes that a contract will not be awarded exclusively on the basis of price. The RFP is not an offer and may be subject to modification or withdrawal under regulations promulgated by the Policy Office. No RFP shall be issued for a procurement of an item costing less than (minimum dollar amount).

(3) Public Notice Adequate public notice of the Request for Proposals shall be given a reasonable time prior to the date set forth therein for opening proposals.

(4) Receipt of Proposals After any proposals except the best and final proposals are opened, the performance specifications, but not the precise innovation, of any proposal may be disclosed to competing proposers only for the purpose of allowing those competing proposers to conform their proposals. Under no circumstances may specific price or design proposals be disclosed. A Register of Proposals shall be prepared in accordance with regulations promulgated by the Policy Office, and shall be open for public inspection after contract award.

(5) Evaluation Factors The RFP shall state the evaluation factors as objective measurable criteria. The evaluative significance of all factors shall be disclosed to all proposers prior to request for the best and final proposals.

(6) Discussion with Responsible Offerors and Revisions to Proposals As provided in the Request for Proposals, and under regulations promulgated by the Policy Office, discussions shall be conducted with responsible offerors who submit proposals determined to be possible selections for contract award. The purpose of these discussions is to assure full understanding of, and responsiveness to, the solicitation requirements. Offerors shall be accorded fair and equal treatment with respect to any opportunity for discussion and revision of proposals, and such revisions may be permitted after RFP 
submissions and prior to award for the purpose of obtaining best and final proposals.

(7) Award Award shall be made to the responsible offeror whose proposal is determined in writing to be the most advantageous to the State taking into consideration price and all evaluation factors set forth in the Request for Proposals. No other factors or criteria shall be used in the evaluation. The contract file shall state the basis on which the award is made. 


\section{APPENDIX II.}

\section{State Procurement Laws}

A. The following eight states have enacted Model Procurement Code-based competitive bidding or competitive negotiation legislation, or both.

Arkansas:

Colorado:

Indiana:

Kentucky:

Louisiana:

Maryland:
ARk. Stat. Ann. $\$ \$ 14-254$ to -256 (1979) (both).

1981 Colo. Sess. Laws 1259 (both).

1981 Ind. Acts No. 162, Pub. L. No. 32 (Burns Advance Legis. Service) (both).

Ky. REv. STAT. $§ \S 45 A .080, .085$ (1980) (both).

LA. Rev. Stat. Ann. § 39:1503 (West Supp. 1981) (negotiation).

Md. Ann. Code art. 21, $\S \$ 3-202$ to -204 (1981 \& Supp. 1981) (both).

South Carolina: Citation not yet available.

Utah:
Utah Code ANN. $\$ \S 63-56-20$ to -21 (Supp. 1981) (both).

B. The following state statutes authorize various forms of competitive bidding and contain no general provisions for the use of Requests for Proposals or competitive negotiation:
Alabama:
AlA. Code $\S \S 41-16-20,-24,-50$ (Supp. 1981).
Alaska:
Alaska Stat. $\$ 37.05 .230$ (1978 \& Supp. 1980).
Arizona:
Ariz. Rev. Stat. AnN. $§ \S 41-729,-730$ (1974 \& Supp. 1980).
California:
CAL. Gov't Code $\$ \S 14250-14275,14290$ - 14335, 14780-14784, 14790-14818 (West 1980).
Connecticut: Conn. Gen. Stat. Ann. $\$ \S 4-112,-114$ (West Supp. 1981).
Delaware:
Del. Code Ann. tit. 29, $\S \S 6903-6907$ (1979 \& Supp. 1980).


Florida:

Georgia:

Hawaii:

Idaho:

Illinois:

Iowa:

Kansas:

Maine:

Massachusetts:

Michigan:

Minnesota:

Mississippi:

Missouri:

Montana:

Nebraska:

Nevada:
Fla. Stat. AnN. $\S \S 287.057, .062$ (West Supp. 1981).

Ga. Code ANn. $\$ \$ 40-1909$ to -1913 (1975 \& Supp. 1981).

Hawail Rev. Stat. $\$ \S 103-22,-25$ to -32 (1976 \& Supp. 1980).

IDAHo CoDE $\S \S 31-4003$ to -4011 (1963 \& Supp. 1981).

ILL. ANN. Stat. ch. 127, §§ 132.1 -.9a (SmithHurd 1981).

Iowa Code Ann. $§ 73.2$ (West 1973).

Kan. Stat. AnN. $\$ \$ 75-3739$ to -3741 (Supp. 1980).

ME. Rev. Stat. ANn. tit. 5, § 1816 (1979 \& Supp. 1981).

Mass. Ann. Laws ch. 7, § 22, (Michie/Law. Co-op 1980).

Mich. Comp. LAws ANN. $\$ \S 18.4(b)$ (1981), 123.501 (1967).

Minn. Stat. Ann. $§ 16.07$ (West 1977 \& Supp. 1981).

Miss. Code Ann. §31-7-13 (Supp. 1981).

Mo. Ann. Stat. $\$ \S 34.040-.065$ (Vernon 1969).

Mont. Code Ann. \$§ 18-1-102, -2-301 (1979).

NEB. REV. STAT. §§ 73-101 to -106, 81-1118(5) (1976, Cum. Supp. 1980 \& Supp. 1981).

Nev. REv. Stat. $\$ \S 333.290-.350$ (1979) (further amended by $1981 \mathrm{Nev}$. Stats. ch. 557 (Adv. Sh. Nev. Legis.)).

New Hampshire: N.H. Rev. Stat. ANN. §8:19 (1971 \& Supp. 1979).

New Jersey: N.J. Stat. ANN. $§ \S 52: 34-6$ to -12 (West 1955 \& Supp. 1981). 
New Mexico: N.M. Stat. ANn. $\$ \S 13-1-9$ to -13 (1978 \& Supp. 1979).

New York:

N.Y. State Fin. Law $§ \S 163-164,166-167$, 174 (McKinney 1974 \& Supp. 1980) (further amended by 1981 N.Y. Laws ch. 584).

North Carolina: N.C. GeN. STat. $\$ \S 143-52$ to -56 (1978) (further amended by 1981 N.C. Adv. Legisl. Serv. chs. 602, 953).

North Dakota: N.D. Gent. CodE $\$ \S 54-44.4-01$ to -06 (Supp. 1979).

Ohio: Ohio Rev. Code Ann. \$§ 125.07-.11 (Page 1978 \& Supp. 1981) (further amended by 1981 Ohio Legisl. Bull. 12, 18-19).

Oklahoma: $\quad$ OkLA. Stat. AnN. tit. $74, \S \S 85.3, .5, .7$ (West 1965 \& Supp. 1980).

Oregon: $\quad$ Or. REv. STAT. $\$ \S 279.015-.029, .035$ (1979).

Pennsylvania: $\quad$ PA. Star. AnN. tit. 71, §§ 187, 1612 (Purdon 1962); tit. 73, $\S \S 1602-1604,1622$ (Purdon Supp. 1981).

Rhode Island: $\quad$ R.I. GEN. LAws $\S \S 42-11-2$ (d) to -2(f) (1977).

South Dakota: $\quad$ S.D. Codified LAws ANN. $\$ \S 5-18-2$ to $-5,-7$ to $-9.2,-18$ (1980 \& Supp. 1981).

Tennessee: TENN. CodE ANN. $\$ \S 12-3-101$ to $-103,-108$ to -110 (1980 \& Supp. 1981).

Texas:

Tex. Rev. Civ. Srat. AnN. art. 601b, §§ 3.08.11 (Vernon Supp. 1980) (further amended by 1981 Tex. Sess. Law Serv. ch. 546).

Vermont:

VT. Stat. ANN. tit. 29, §902 (1970).

Virginia:

VA. Code $\$ \S 11-17$ to $-17.1,-20$ to -21 (Supp. 1981).

Washington: WASH. REv. CODE ANN. $\$ \S 43.19 .190, .1906$, .1911 (Supp. 1981).

West Virginia: W. VA. CoDE $\$ \S 5 A-3-3$ to $-5,-11$ to -14 (1979 \& Supp. 1981). 
Wisconsin:

Wis. Stat. Ann. $\$ \S 16.71, .72, .75$ (1981) (further amended by 1981 Wis. Legis. Serv. 101,115 (ch. 20, §87q)).

Wyoming:

WYo. StaT. §§ 9-3-2021(b)(vii), -2021(b)(viii), -2021 (b)(xiv) (1977). 